\title{
STRATEGI KEPALA MAN GUNUNG PADANG PANJANG DALAM MENINGKATKAN NILAI AKREDITASI LEMBAGA
}

\author{
Syaiful Arifin \\ Kasi Haji Kementerian Agama Kota Padang Panjang, Sumatera Barat \\ e-mail: a rifinsyaifula rifin@gmail.com
}

\begin{abstract}
This reaserch was done to know about the Strategy headmaster MAN Gunung Padang Panjang increasing value of accreditation. This study uses a qualitative method using a case study perspective deskriptif. Teknik data collection in the form of observation, interviews and documentation study. The results of this study, 1). Strategy headmaster in improving the value of accreditation: a) Establish a madrasah accreditation team. b) Uniting the whole perception of madrasah stakeholder to increase the value of accreditation. $c$ ) develop a vision and mission and strategic plan of the madrasah. d) Inviting community leaders actively promote madrasah.e). Every effort to improve education standard eight 2). Barriers faced by the headmaster is: a) The attitude of teachers varies proactive in achieving the implementation of the vision and mission of the madrasas., B). Professionalism of teachers who have not honed well. c). There are still teachers who like comfortable or just come madrasah when teaching hours. $d$ ). There is still a teacher less concerned about the activities of the madrasas, facilities and infrastructure is not yet complete. 3). Implementation of the strategy undertaken headmaster: a) Make a commitment with educators and stakeholders to advance the institution, b) Develop EDS, c) vision and mission madrasah, d). make strategic plan, e) Establish Accreditation Team, f) empower school committee, and g) to collaborate with relevant agencies.
\end{abstract}

Keywords: Strategy, Principals, Accreditation

\section{PENDAHULUAN}

Madrasah berkewajiban untuk meningkatkan mutu lembaga karena madrasah sebagai lembaga pendidikan merupakan bagian integral dari masyarakat, yang berhadapan dengan kondisi nyata masyarakat dengan segala masalah yang komplek. Lembaga pendidikan dituntut untuk mampu menjawab masalah yang terjadi masyarakat, salah satu indikator sekalah dinilai bermutu ketika lembaga itu mampu memenuhi harapan orang tua. Maju mundurnya sebuah lembaga pendidikan ditentukan oleh kemampuan yang dimiliki seorang kepala madrasah. Kepala madrasah memiliki peran yang sangat besar dalam mengembangkan lembaga pendidikan. Samino (2012: 41) mengungkapkan "kepala sekolah merupakan kunci yang sangat menentukan 
keberhasilan sekolah. Keberhasilan sebuah lembaga pendidikan dibuktikan dengan kualitas lulusan dari lembaga tersebut hal ini dibuktikan dengan tingginya tingkat penerimaan diperguruan tinggi, prestasi siswa dibidang ekstrakurikuler, tingkat kepedulian masyarakat dalam mendukung proses belajar mengajar pada lembaga tersebut, tersedianya sarana prasarana yang lengkap untuk mewujudkan kualitas output sekolah, kepuasan wali murid terhadap kualitas output sekolah dan lai-lain.

Peningkatan mutu madrasah tidak terlepas dari kemampuan manajemen dan strategi yang digunakan kepala madrasah untuk meningkatkan mutu madrasahKalau dikaitkan dengan pendidikan maka yang menjalankan fungsi-fungsi manajemen itu adalah kepala sekolah/madrasah. Dalam menjalankan fungsinya kepala sekolah/ madrasah tidak hanya sebagai seorang maneger tetapi memiliki fungsi-fungsi perencanaan, pengorganisasian, pelaksanaan dan evaluasi. Di samping itu kepala sekolah bukan hanya sebagai seorang guru, tetapi memiliki peran yang sangat komplek. Selain kriteria yang seharusnya dimiliki oleh seorang kepala sekolah, maka kepala sekolah juga harus memiliki strategi khusus untuk meningkatkan mutu madrasah. Salah satu indikator meningkatnya mutu madrasah adalah penilaian yang dilakukan oleh BAS Nasional. Akreditasi sekolah adalah suatu kegiatan penilaian kelayakan dan kinerja suatu sekolah berdasarkan kriteria (standar) yang dilakukan Badan Akreditasi Sekolah yang hasilnya diwujudkan dalam bentuk pengakuan peringkat kelayakan sebagaimana diatur dalam Keputusan Menteri Pendidikan Nasional nomor 087/U/2002.

Berdasarkan pengertian di atas maka akreditasi sekolah adalah usaha untuk menilai kelayakan setiap sekolah dengan membandingkan kenyataan yang ada dengan standar yang telah ditetapkan. Alat ukur yang digunakan adalah 8 standar pendidikan nasional. Apabila ditemukan kondisi sekolah memiliki standar yang sama dengan kriteria yang telah ditetapkan maka sekolah itu terakreditasi. Sebaliknya, jika kemampuan sekolah dibawah standar yang telah ditetapkan maka sekolah tidak terakreditasi. Akreditasi sekolah dilaksanakan mulai dari TK/RA, SD/ MI, SMP/MTs, SMA/MA dan Perguruan Tinggi. Penilaian akreditasi akan mempengaruhi mutu sekolah dan tingkat kepercayaan masyarakat terhadap lembaga pendidikan. Setiap lembaga pendidikan akan berusaha semaksimal mungkin untuk meningkatkan nilai akreditasi nya. Salah satu lembaga pendidikan yang terus berupaya meningkatkatkan nilai akreditasi madrasah adalah MAN Gunung Padang Panjang.

Untuk melihat efektivitas strategi yang digunakan kepala madrasah dalam meningkatkan nilai akreditasi lembaga peneliti mencoba mengamati bagaimana pelaksanaan pelaksanaan strategi yang diterapkan kepala MAN Gunung Padang Panjang. Alasan peneliti memilih MAN 
Gunung sebagai tempat penelitian dilatar belakangi pengamatan yang penulis lakukan menemukan kemajuan yang signifikan pada MAN Gunung Padang Panjang terutama dari berbagai aspek. Perubahan ini terasa cukup nampak setelah terjadi suksesi kepemimpinan Kepala Madrasah dari Bapak H. Mirdas Ilyas. S.Ag (memasuki masa pensiun) kepada Bapak Amrizon S.Pd.

Di antara kemajuan yang peneliti temukan adalah, peningkatan jumlah siswa, peningkatan Sarana Prasarana, peningkatan dukungan masyarakat terhadap madrasah, peningkatan jumlas siswa yang diterimadi Perguruan Tinggi, Peningkatan Prestasi Akademik siswa, peningkatan prestasi Ekstra kurikuler, peningkatan Nilai Akreditasi lembaga. Dengan melihat kemajuan yang terjadi di MAN Gunung Padang Panjang peneliti tertarik untuk meneliti "Strategi Kepala MAN Gunung Padang Panjang dalam Meningkatkan Nilai Akreditasi Lembaga”.

\section{METODE PENELITIAN}

Metode penelitian adalah suatu cara sebagai usaha untuk menemukan, mengembangkan dan menguji kebenaran suatu pengetahuan dalam upaya memecahkan suatu pengetahuan dalam upaya memecahkan suatu permasalahan dengan menggunakan metode ilmiah. Dengan metode penelitian pekerjaan penelitian akan lebih terarah, sebab metode penelitian bermaksud memberikan kemudahan dan kejelasan tentang apa dan bagaimana penelitian melakukan penelitian. Oleh karena itu dalam bab tiga ini akan diuraikan mengenai berbagai hal yang termasuk dalam metodologi penelitian.

Pendekatan kualitatif ini dipilih untuk digunakan dalam penelitian dengan bermaksud untuk memahami perilaku manusia dari kerangka acuan si pelaku sendiri yakni bagaimana si pelaku memandang dan menafsirkan dari segi pendiriannya yang biasa disebut dengan persepsi emik begitu juga agar dapat mengetahui dan mendeskripsikan secara jelas dan rinci tentang Strategi Kepala MAN Gunung Padang Panjang dalam meningkatkan nilai akreditasi lembaga.

Dalam penelitian ini memakai perspektif fenomenologi yaitu peneliti memahami dan menghayati perilaku atau kegiatan para pemimpin dalam rangka melaksanakan Strategi Kepala MAN Gunung Padang Panjang dalam meningkatkan nilai akreditasi lembaga. Untuk memahami, menghayati, realitas empiris tersebut, maka peneliti mengimplementasikan, membandingkan hasil terdahulu dan referensi sebagai bahan rujukan untuk memahami dan mengimplementasikannya.

Data kualitatif adalah data yang tidak dapat diukur dengan bilangan atau tak dapat diutarakan dalam bentuk angka-angka, tetapi dalam bentuk kategori-kategori yang exhaustive, artinya satu unsur hanya dapat dimasukkan dalam salah satu kategori. (Hanif, 2011: 72) Sejalan dengan hal ini 
menurut Ruslan Ahmad menjelaskan, bahwa data kualitatif adalah apa yang dikatakan oleh orang-orang berkaitan seperangkat pertanyaan yang diajukan oleh peneliti apa yang dikatakan oleh orang-orang merupakan sumber utama dalam data kualitatif, apa yang mereka katakan itu diperoleh secara verbal melalui wawancara atau dalam bentuk tertulis melalui analisa dokumentasi atau respons survey. (Ahmad, 2005: 63)

Menurut Lexy Maleong (1996: 12-48) menjelaskan, sumber data utama dalam penelitian kualitatif ialah kata-kata dan tindakan, selebihnya merupakan data tambahan seperti dokumen dan sumber data yang lainnya. Jadi sumber data dalam penelitian ini adalah kata-kata yang diperoleh dari informasi dan dokumen yang merupakan data tambahan.

Sedangkan sumber data dalam penelitian ini adalah orang yang banyak atau berkecimpung langsung di Madrasah Aliyah Gunung Padang Panjang yaitu kepala madrasah, semua majelis guru serta siswa. Pemilihan informan dalam penelitian ini adalah dengan teknik snowball sampling yaitu informan kunci akan menunjukkan orang yang mengetahui masalah-masalah yang akan diteliti untuk melengkapi keterangan-keterangan dan orang yang ditujukan akan menunjukkan orang lain bila keterangan yang diberikan kurang bisa memahami dan seterusnya. Teknik ini akan bermanfaat bagi peneliti sebagai validitas data yang diberikan oleh informan.

\section{HASIL PENELITIAN DAN PEMBAHASAN}

Madrasah Aliyah Negri Gunung Padang Panjang sebagai salah satu madrasah yang tertua di kota Padang Panjang telah mengalami pasang surut dan berganti pimpinan, yang mana hal ini memberikan kematangan kepada MAN Gunung Padang Panjang. Sesuai dengan perkembangan zaman MAN Gunung selalu berupaya mengikuti perkembangan zaman dan selalu berinovasi untuk meningkatkan pelayanan dalam bidang pendidikan.

Di antara hal yang mesti dipenuhi oleh MAN Gunung Padang Panjang adalah meningkatkan nilai akreditasi Lembaga. Ketika terjadi suksesi kepemiminan MAN Gunung Padang Panjang dari Bapak Mirdas S.Ag kepada Bapak Amrizon. SPd. Kondisi madrasah saat itu nilai akreditasinya " $B$ ". Dalam waktu 3,5 Tahun nilai akreditasi MAN Gunung bisa meningkat menjadi "A" (Amat Baik) berdasarkan Keputusan Badan Akreditasi nasional Sekolah Madrasah (BAN-S/M) tanggal 12 November 2012 berlaku sampai tahun 2017.

Dari wawancara yang penulis lakukan denganInforman 1. Kepala MAN Gunung Padang Panjang hari selasa tanggal 14 juli 2016 bertempat di Ruang kepala MAN Gunung Padang Panjang diperoleh keterangan tentang kondisi madrasah ketika beliau ditugaskan di MAN Gunung Padang Panjang sebagai berikut:

1. Kondisik fisik madrasah terkesan suram tidak berseri dan kurang nyaman dan 
kurang terawat serta tidak mendukung suasana proses belajar mengajar.

2. Jumlah siswa hanya enam rombel dengan jumlah siswa 136 orang.

3. Motivasi bertugas guru dan tenaga kependidikan belum mksimal.

4. Rasa percaya diri siswa rendah untuk menyebutkan sekolah di MAN Gunung

5. Rasa memiliki dan percaya diri dan menyebutkan diri mengajar di MAN Gunung.

6. Motivasi berprestasi siswa belum maksimal.

7. Motivasi mengajar guru belum optimal.

8. Persepsi masyarakat PBM belum optimal, dipengaruhi, Lokasi sekolah dipertigaan, anak cepat pulang bermain pada jam plajaran, ada lokasi bilyar yang mengakibatkan rendahnya animo msyarakat memasukkan anak ke madrasah.

9. Keadaan tenaga PTK Guru Pns, 14, guru GTT 12 tenaga kependidikan 3 orang. Yang berpengaruh kepada semangat kerja, guru hanya datang saat nmengajar, guru cepat pulang.

10. Kegiatan eskul hanya pramuka Kegiatan Asrama belum optimal lebih mirip rumah kos belum ada pembinaan asrama.

11. Madrasah Aliyah Negeri Gunung Padang Panjang Menjadi Alternatif terakhir bagi masyarakat kota Padang Panjang untuk melanjutkan pendidikan.

12. Akreditasi sekolah B Kurus, target pembenahan 2-3 tahun untuk mewujudkan akreditasi "A".
Setelah mencermati kondisi madrasah maka strategi yang dilakukan kepala madrasah untuk membenahi dan meningkatkan nilai akreditasi MAN Gunung menjadi lebih baik. Istilah Strategi berasal dari bahasa Yunani Strategeia (Stratos $=$ militer dan ag = memimpin) yang artinya seni atau ilmu untuk menjadi jendral. Menurut Kolter dalam Nining I Soesilo (h.7-9), strategi merupakan sekumpulan cara-cara untuk untuk mencapai tujuan, sehingga strategi menjadi suatu pendekatan logis. Sedangkan menurut James Brian Quin dalam Nining I Soesilo (h.7-9): Strategi adalah incremental approach yaitu: pola atau rencana yang mengintegrasikan tujuan utama, kebijakan dan urutan-urutan tindakan organisasi menjadi satu dalam keseluruhan yang kohesif. (Solehan: 2013)

Beberapa pakar lain mengemukakan defenisi strategi sebagai berikut:

1). Menurut David (2004: 15) strategi adalah cara untuk mencapai tujuan

2). Menurut Hunger (1995: 129) strategi adalah merupakan program perencanaan perusahaan untuk mencapai tujuan perusahaan dengan memaksimalkan keunggulan bersaing dan meminimalisasi kesalahan.

3). Menurut Porter (1985) (Freddy Rangkuty, 1997). Strategi adalah alat yang sangat penting untuk mencapai keunggulan bersaing.

4). Menurut Argyris (1985), Mintzberg (1979) Steiner dan Miner (1977) dalam 
(Freddy Rangkuty, 1997). Strategi adalah merupakan respon terus menerus maupun adaptif terhadap peluang dan ancaman eksternal serta kekuatan dan kelemahan internal yang dapat mempengaruhi organisasi.

Dari beberapa pengertian diatas maka dapat dirumuskan "strategi ada metode yang digunakan untuk melakukan perencanaan pengorganisasian pelaksanaan dan pengawasan yang dilakukan secara kontinu dengan meminimalisir kelemahan yang ada untuk mencapai tujuan organisasi" strategi yang dimaksudkan dalam tulisan ini adalah metode yang digunakan kepala madrasah dalam melakukan perencanan pengorganisasian pelaksanaan dan pengawasan yang dilakukan secara kontinu dengan meminimalisir kelemahan yang ada untuk mencapai tujuan madrasah"

Strategi adalah kunci suksesnya dalam mencapai tujuan madrasah. Kepala madrasah yang baik adalah kepala madrasah yang memiliki strategi jitu dalam memajukan madrasahnya. Tanpa ada strategi maka program madrasah tidak akan berjalan. Starategi adalah langkah awal dan terpenting ketika pemimpin berniat memajukan madrasah.Sehebat apapun seorang pimpinan jika iatidak memiliki strategi yang baik dan jitu maka programnya akan tak berarti. Kepemimpinan tidak hanya mengadalkan kemampuan sang pemimpin namun juga strategi sang pemimpin. Adapun strategi Kepala MAN Gunung adalah:

\section{Strategi Kepala Madrasah dalam Meningkatkan Nilai Akreditasi Lembaga}

\section{a. Membentuk Tim Akreditasi Madrasah}

Tim akreditasiditetapkan dengan surat keputusan. Tim terdiri dari 8 bagian sesuai dengan 8 standar yang ditetapkan BNSP Sekolah/Madrasah. setiap tim terdiri dari 4-5 orang anggota, menyusun rencana kerja, membuat pembagian kerja, menetapkan waktu pelaksanaan kegiatan dan mengadakan evaluasi secara berkala:

"Menurut keterangan Informan 3 (2016) waka humas MAN Gunung Padang Panjang di antara kelebihan Bapak Amrizon S.Pd sebagai Kepala Sekolah selalu mempunyai Prosedur Operasional Standar yang jelas setiap penugasan yang diberikan kepada guru selalu dilakukan evaluasi secara berkala, untuk melihat kemajuan tugas yang diberikan.”

\section{b. Menyatukan Persepsi SeluruhStakeholder Madrasah untuk Meningkatkan Nilai Akreditasi lembaga}

Dalam pertemuan tersebut kepala madrasah mengajak seluruh komponen yang ada di madrasah untuk melakukan hal sebagai berikut:

1). Mengajak semua pendidik dan tenaga kependidikan untuk bersyukur dan bangga bisa mengabdi dan mencerdaskan anak bangsa melalui madrasah, bahwa pengabdian yang dilakukan tidak hanya berkontribusi kepada ekonomi kepada tenaga pendidik dan kependidikan yang lebih besar lagi setiap ilmu yang 
diajarkan akan menjadi investasi amal diakhirat.

2). Mengajak seluruh komponenen pendidik dan tenaga kependidikan untuk mencintai madrasah seperti rumah sendiri sehingga akan berdampak kepada suasana proses belajar mengajar menjadi nyaman.

3). Memberikan kesempatan kepada seluruh masyarakat madrasah untuk ikut menyumbangkan ide-ide dan saran untuk kemajuan madrasah.

4). Melibatkan seluruh stakeholder yang ada di madrasah dalam pengambilan keputusan.

\section{c. Menyusun Menetapkan Visi Madrasah}

Dalam menyusun visi dan misi madrasah kepala madrasah menggunakan format EDS dan Swot analisis. Analisis SWOT adalah suatu analisa penyusunan strategi perusahaan atau organisasi yang bersifat tunggal. Ruang lingkup bisnis tunggal yang bersifat domestik atau internasional. Menurud Fredi Rangkuti pakar analisis SWOT Indonesia analisis swot adalah:

"Identifikasi berbagai faktor secara sistimatis untuk merumuskan strategi perusahaan. Analisa ini didasarkan atas pola hubungan atau interaksi antara unsur-unsur internal, kekuatan dan kelemahan terhadap unsur-unsur eksternal yaitu peluang dan ancaman (Rahman: 2011)
Hasil identifikasi yang dihasilkan dengan analisa swot adalah:

\section{1). Strength (Kekuatan)}

Kepala madrasah bersama civitas akademika MAN Gunang berusaha menginventarisir semua kekuatan:

a). Guru berpendidikan S1 dan S2

b). Motivasi belajar siswa cukup tinggi

c). Komitmen guru melaksanakan tugas tinggi

d). Sarana Prasarana cukup memadai

e). Rangking dan reputasi baru mulai bergerak kearah yang lebih baik

f). Lingkungan belajar sangat kondusif

g). Bakat dan potensi siswa cukup memadai

h). Dukungan masyarakat sedang

i). Guru mampu mengembangkan kreatifitas pembelajaran.

\section{2). Weakness (Kelemahan)}

Dari evaluasi madrasah yang dilakukan ditemukan beberapa kelemahan:

a). Penyebaran guru bidang studi belum merata

b). Belum semua guru memperoleh pelatihan

c). Buku pegangan siswa belum memadai

d). Latar belakang orang tua siswa masih rendah

e). Rata-rata nem input siswa rendah

f). Minat masyarakat untuk memasukkan anaknya ke madrasah rendah. 


\section{3). Opportunities (Keberuntungan)}

a). Kualitas pembelajaran dapat ditingkatkan

b). Banyaknya sekolah tingkat SLTP disekitar

c). Banyaknya kesempatan siswa untuk masuk Perguruan Tinggi melalui jalur PMDK

d). Kesempatan bagi siswa masuk PTAIN cukup besar

e). Kesempatan untuk memperoleh beasiswa dari Kemenag, Pemda, Kota Padang Panjang dan Pemda Propinsi Sumatera Barat.

\section{4). Threat (Ancaman)}

a). Lokasi madrasah jauh dari pusat kota

b). Persaingan SLTA di Padang Panjang cukup tinggi

c). Masih terjadi perkelahian pelajar disekolah sekitar

d). Risiko bahaya narkoba cukup tinggi

e). Masih banyak siswa yang tinggal jauh dari lokasi sekolah.

\section{d. Mengajak tokoh masyarakat berperan aktif memajukan Madrasah.}

Upaya yang dilakukan kepala sekolah dengan mengadakan pendekatan persuatif kepada tokoh masyarakat, ninik mamak, ketua pemuda, bundo kandung langkah yang dilakukan adalah:

1). Mengadakan pertemuan di madrasah dengan tokoh masyarakt, ninik mamak, tokoh pemuda, bunda kandung;
2). Memberikan pemahaman akan dampak positif keberadaan madrasah kepada nagari Gunung. Semakin dikenal nagari Gunung diluar kota Padang Panjang

3). Menjelaskan kepada tokoh msyarakat, ninik mamak, tokoh pemuda, bundo kandung dampak ekonomi keberadaan madrasah bagi masyarakat Gunung.

4). Meminta kesediaan tokoh masyarakat menjadi ketua komite DR.Novi Hendri Dt. Bagindo Saidi.

\section{e. Mengupayakan Peningkatan Delapan Standar Pendidikan Nasional}

Untuk mewujudkan peningkatan nilai akreditasi madrasah sebagai standar kelayakan sebuah lembaga dalam menyelenggarakan pendidikan maka cara yang diakukan kepala madrasah adalah:

\section{1). Meningkatkan Standar Kelulusan.}

Dalam meningkatkan standar kelulusan maka cara yang ditempuh oleh kepala madrasah adalah:

a). Menetapkan Kurikulum berdasarkan KTSP kurikulum tahun 2006 dan kurikulum madrasah.

b). Menyusun daftar pembagian tugas guru

c). Mengefektifkan proses belajar mengajar

d). Tidak boleh guru naik jam atau mengajar diluar jam yang telah ditantukan.Anak tidak dibenarkan berada diluar kelas. 
"Lokal tidak boleh kosong, anakanak tidak boleh berkeliaran saat jam belajar, PBM tidak boleh terganggu dengan guru yang tidak hadir" (Informan 4: 2016).

\section{2). Meningkatkan Standar Isi}

Upaya yang dilakukan kepala madrasah dalam meningkatkan standar isi adalah

a). Menyiapkan guru mahir menggunakan KTSP melalui pelatihan dan MGMP

b). Menjalin kerjasama dengan dinas Pendidikan Kota Padang Panjang untuk melakukan pelatihan kepada guru MAN Gunung Padang Panjang.

c). Mengirim guru mengikuti pelatihan di Balai Diklat Teknis Keagamaan Padang.

d). Mengirim guru mengikuti Seminar dan lokakarya kependidikan sesuai bidang studi yang diampunya.

e). Mengusulkan DDTK ke balai diklat teknis keagaamaan Padang

"Hasil wawancara dengan informan 4 (2016) hari Selasa 12 juli 2016 beliau menjelaskan Kepala sekolah pro aktif menjalin komunikasi dengan instansi terkait seperti dengan dinas Pendidikan, Balai Diklat Keagamaan agar guru MAN Gunung memperoleh prioritas mengikuti Diklat"

\section{3). Meningkatkan Standar Proses}

a). Meningkatkan aplikasi dari hasil diklat, setiap guru yang kembali dari diklat diharuskan memberi informasi terbaru kepada guru yang belum diklat (Informan 4: 2016)

b). Mengirim guru mengikuti diklat assesor

c). Membentuk tim supervisi yang akan membantu kepala sekolah melakukan supervisi teman sejawat

d). Menyusun format penilaian kompetensi guru

4). Meningkatkan Standar Tenaga Pendidik dan Kependidikan

a). Menetapkan standar pendidik yang memenuhi kriteria kompetensi pedagogik kompetensi kepribadian, kompetensi profesional, dan kompetensi sosial melalui diklat dan pelatihan b). Menambah tenaga kependidikan staf dengan persyaratan minimal tamatan SLTA, memiliki kemampuan mengoperasikan komputer, taat beribadah, danmemiliki dedikasi tinggi.

b). Mengusulkan penambahan tenaga pendidik melalui Kantor Kementerian Agama Kota Padang Panjang untuk diusulkan ke Kanwil Kementerian Agama Propinsi Sumatera Barat, terealisasi 5 orang

"Berdasarkan wawancara dengan informan 5 (2016) KaurTUMAN Gunung permintaan tambahan tenaga pendidik diusukan melalui Kantor Kementerian Agama Kota Padang panjang dengan menyusub Bezetting formasi. Dan 
telah diperoleh tambahan guru PNS 5 Orang dan penambahan pegawai PTT 7 orang."

\section{Meningkatkan Standar Sarana Prasarana}

Pada awal pertama kepala MAN Gunung Padang Panjang dilantik pada bulan agustus 2008 kondisi sarana prasarana yang tersedia di MAN Gunung Padang Panjang adalah sebagai berikut:

Tabel 26 Keadaan Sarana Prasarana

\begin{tabular}{|c|l|l|l|l|}
\hline No & \multicolumn{1}{|c|}{ Sarana } & \multicolumn{1}{c|}{ Sebelum } & Sekarang & Satuan \\
\hline 1 & Lokal & 12 & 14 & Unit \\
\hline 2 & Labor IPA & 1 & 1 & Unit \\
\hline & & & 1 & \\
\hline 3 & Labor Agama & - & 1 & - \\
\hline 4 & Labor komputer & 1 & 1 & Unit \\
\hline 4 & Asrama Putri & 1 & 1 & Unit \\
\hline 5 & Asrama Putra & - & 1 & \\
\hline 6 & Kantor & 1 & 1 & Unit \\
\hline 7 & Mushalla & 1 & 1 & Unit \\
\hline 8 & Pos Satpam & 1 & 1 & Unit \\
\hline 9 & Ruang Osis & 1 & 1 & Unit \\
\hline 10 & Ruang BK & - & 1 & Unit \\
\hline 11 & Ruang UKS & - & 1 & Unit \\
\hline 12 & RuangKKR & - & 1 & Unit \\
\hline 13 & Kantin & - & 2 & Unit \\
\hline 14 & WC Guru/Kepala & 1 & 3 & Unit \\
\hline 15 & WC Siswa & 4 & 10 & Unit \\
\hline
\end{tabular}

Untuk meningkatkan jumlah dan kualitas sarana prasaran cara yang dilakukan oleh kepala madrasah adalah:

a). Membuat master plan madrasah sesuai dengan visi dan misi madrasah

b). Mempresentasikan master plan dihadapan komite madrasah agar komite ikut berpartisipasi mengembangkan sarana prasarana madrasah.

c). Mempresentasikan master plan dihadapan Kepala Kantor Kementerian Agama
Kota Padang Panjang untuk diusulkan di APBN

d). Membuat proposal dan memasukkan usulan di Musrembang kelurahan untuk diusulkan di APBD.

e). Mempresentasikan program sekolah kepada donatur

f). Melibatkan seluruh civitas akademika MAN Gunung Padang Panjang kepada donator yang tidak mengikat.

Dari upaya yang dilakukan di atas maka diperoleh hasil sebagai berikut:

Berdasarkan wawancara dengan informan 5 (2016) pada hari kamis 23 Juni 2016 dijelaskan:

"Untuk meningkatkan sarana prasarana pada MAN Gunung Padang Panjang dibuat cetak biru/ Advice plane dan tata ruang MAN Gunung Padang Panjang, disusun TOR (Term of Reference), RAB (rincian anggaran biaya) kemudian diusulkan melalui APBD /kota Padang Panjang melalui Musrembang mulai tingkat kelurahan sampai musrembang tingkat Kota dan diperoleh bantuan Rp.50 juta untuk pembangunan Asrama Putra, Kemudian diusulkan melalui Kantor Kementerian Agama Kota Padang Panjang dan diteruskan ke Kanwil Kemenag Sumbar untuk diusulkan melalui APBN dan diperoleh $3 \mathrm{RKB}$ (ruang kelas baru) dan rehab labor 200 juta."

\section{Meningkatkan Standar Pengelolaan.}

Dalam meningkatkan staandar pengelolaan maka cara yang dilakukan kepala madrasah adalah: 
a). Membuat komitmen dengan seluruh stakholer yang ada di madrasah yang terdiri dari tenaga pendidik dan kependidikan, komite dan siwa serta orang tua untuk memajukan madrasah.

b). Mengembangkan gaya kepemimpinan transformasional yaitu melibatkan seluruh komponen yang ada dalam mewujudkan visi dan misi madrasah. Gaya kepemimpinan dijelaskan sebagai suatu proses, perilaku atau hubungan yang membentuk pola tertentu yang menyebabkan suatu kelompok untuk bertindak secara bersama-sama atau bekerja sama sesuai dengan aturan dan atau tujuan bersama (Sarwono, 1999: 40). Konsep gaya kepemimpinan ini menunjukkan adanya kombinasi bahasa, tindakan dan kebijakan tertentu, yang menggambarkan pola yang cukup konsisten yang digunakan oleh pemimpin dalam membantu orang lain/ bawahan/kelompoknya dalam mencapai hasil yang diinginkan bersama (Pace $\&$ Faules, 1998: 277).

Pendapat serupa dikemukakan oleh Robbins (2002: 3) yang berpendapat bahwa gaya kepemimpinan merupakan suatu strategiatau kemampuan dalam mempengaruhi suatu kelompok ke arah tercapainya tujuan. Menurut Bass (1985, dalam Wutun, 2001: 345), gaya kepemimpinan adalah kemampuan mempengaruhi suatu hubungan yang cenderung mengikuti pola/strategi tertentuuntuk pencapaian tujuan bersama. Sedangkan Lewis (dalam Jewel \& Siegal, 1998: 435) menyatakan bahwa gaya kepemimpinan merupakan suatu pengaruh dari seorang pemimpin terhadap kelompok atau pengikutuntuk meningkatkan kepatuhan dalam usaha mencapai tujuan bersama.

Menurut Wutun (2001: 345) salah satu konsep kepemimpinan yang dapat menjelaskan secara tepat pola perilaku kepemimpinan atasan yang nyata ada dan mampu memuat pola-pola perilaku dari teori kepemimpinan lain adalah kepemimpinan transformasional dari Bass (dalam Wutun, 2001: 350), menyatakan bahwa gaya kepemimpinan transformasional cenderung membangun kesadaran para bawahannya mengenai pentingnya nilai kerja dan tugas mereka. Pemimpin berusaha memperluas dan meningkatkan kebutuhan melebihi minat pribadi serta mendorong perubahan tersebut ke arah kepentingan bersama termasuk kepentingan organisasi (Wutun, 2001: 352).

Berdasarkan wawancara dengan informan 5 (2016): "Kepala madrasah memberikan kesempatan yang luas kepada seluruh stakeholder madrasah untu berpartisipasi untuk peningkatan mutu baik berupa saran, ide konstruktif atau berperan aktif dalan kegiatan"

Menurut Hay (2004) seorang pemimpin transformasional akan berusaha memotivasi, membangkitkan 
semangat dan minat para bawahan, di samping itu tetap berusaha meyakinkan akan tujuan dan misi organisasi. Pemimpin transformasional juga akan berusaha melihat, memperhatikan, mengenali kemampuan individu yang berguna untuk organisasi. Pemimpin transformasional berusaha meyakinkan bawahan bahwa untuk bersama-sama menciptakan produktivitas kerja tinggi, usaha keras, komitmen, dan kapasitas kerja yang tinggi.

Menurut Yammarino dan Bass (1990, dalam Daryanto, 2005) pemimpin transformasional merupakan pemimpin yang karismatik dan mempunyai peran sentral dan strategis dalam membawa organisasi mencapai tujuannya. Pemimpin transformasional juga mempunyai kemampuan untuk menyamakan visi masa depan dengan bawahannya, serta meningkatkan kebutuhan bawahan pada tingkatyang lebih tinggi dari pada apa yang mereka butuhkan. Pemimpin transformasional harus mampu membujuk para bawahannya melakukan tugas-tugas mereka melebihi kepentingan mereka sendiri demi kepentingan organisasi yang lebih besar. Pemimpin transformasional juga akan berusaha mengartikulasikan visi masa depan organisasi yang realistik, menstimulasi bawahan dengan cara yang intelektual, dan menaruh parhatian pada perbedaan-perbedaan yang dimiliki oleh bawahannya.
Munandar dan Wutun (2001: 379) menyatakan bahwa kepemimpinan transformasional yang dikemukakan oleh Bass mempunyai kesamaan dengan konsep kepemimpinan Ki Hajar Dewantara yaitu seorang pemimpin harus mampu berada di depan menjadi tauladan (Ing ngarso sung tulodo), berada di tengah-tengah pengikutnya menghimpun kekuatan bersama (Ing madya mangun karsa), dan berada di belakang untuk selalu memotivasi pengikutnya dan mengarahkan ke tujuan yang tepat (tut wuri handayani).

c). Menerapkan manajemen terbuka dimana kepala madrasah secara terbuka menerima masuka usul dan saran dari semua unsur.

d). Menerapkan fungsi manajemen secara utuh yang meliputi perencanaan, pengorganisasian, pelaksanaan dan pengendalian

e). Selalu memberikan pembinaan dengan pendekatan persuasif.

\section{Meningkatkan Standar Pembiayaan}

Berdasarkan PP 48 tahun 2008 bahwa dana penyelenggaraan pendidikan menjadi tanggung jawab pemerintah, pemerintah daerah masyarakat dan orang tuawali murid. Maka kepala madrasah mencoba menelusuri peran masyarakat dalam membantu keuangan madrasah. Di awal masa jabatan kepala madrasah ditemui setiap siswa membayar sumbangan komite sebanyak Rp.30.000. Dari dana yang terimpun dari 
siswa tersebut sebagian besar diperuntukkan bagi pembayaran hohor guru sukarela, sehingga tidak banyak dana tersebut kembali untuk siswa. Hal ini menyebabkan kegiatan ekstra kurikuler siswa dan pengembangan profesional guru tidak dapat dilakukan secara maksimal. Hal itu juga berpengaruh kepada kesempatan berprestasi siswa tidak optimal. Berdasarkan kondisi di atas maka cara yang dilakukan kepala madrasah adalah:

Merumuskan program madrasah sesuai visi dan misi dan mempresentasikan dihadapan komite dan orang tua siswa, berupa kegiatan ekstra kurikuler, akademik, pengembangan kompetensi profesional guru:

a). Membuat program madrasah dan menyampaikan pada komite

b). Menyusun estimasi biaya kebutuhan sekolan dengan kriteria dana dari DIPA Madrasah, dana BOS, dan kekurangan dana diharapkan bantuan orang Tua wali murid.

c). Komite Mempresentasikan program sekolah dihadapan orang tua wali murid

d). Menerapkan manajemen keuangan terbuka, orang tua wali murid diberi keluasaan meminta keterangan kepada pengurus komite

e). Mengumumkan secara terbuka tentang BOS, BSM, beasiswa BAZDA Kota Padang Panjang

f). Menjelaskan kepada orang tua siswa bahwa tanggung jawab pendidikan itu.
Sekaitan dengan sumbangan orang tua wali murid ketua Komite menjelaskan "Wali Murid MAN Gunung Padang Panjang mendukung program yang dibuat Komite Madrasah karena setiap program yang kita rencanakan dapat dipertanggung jawabkan secara transparan, baik pembangunan phisik maupun kegiatan ektra kurikuler hal ini dibuktikan dengan meningkatnya prestasi siswa dan guru di berbagai iven yang diikuti." (Informan 2: 2016)

\section{Meningkatkan Standar Penilaian Pendidikan}

Untuk meningkatkan nilai standar penilaian maka cara yang dilakukan kepala madrasah adalah:

a). Memperbaiki proses interaksi Proses yang dimaksudkan adalah memperbaiki pola hubungan internal antara guru dan siswa dengan membudayakan tegur sapa yang santun seperti panggilan kepada guru, bunda, bundo amak, ibu/ bapak dan guru memanggil anak didiknya dengan sebutan nanda.

b). Menghilangkan sekat antara siswa dan guru dengan cara menanamkan kepada siswa dan guru bahwa tidak ada siswa yang bodoh dan tidak ada guru yang pemarah dan suka mendiskreditkan siswa antara guru dan siswa sebagai partner yang akan saling memberi dan menerima.

c). Membuat angket penilaian guru untuk mengetahui sisi-sisi yang harus ditingkatkan kualitasnya oleh seorang guru. 
d). Kepala sekolah akan memberikan supervisi kepada guru untuk meningkatkan kompetensinya sebagai seorang guru

e). Menggunakan AVO (Alat visual optik) supervisi

f). Menggunakan KKM (Kriteria Ketuntasan Minimal)

Pada awalnya KKM MAN Gunung hanya antara 50-60 setelah menggunakan strategi ini KKM MAN Gunung berkisar antara 65-70. Dasar penggunaan KKM dengan Imtake (kemampuan belajar siswa), Kompleksitas (materi ajar), dan daya dukung (Sarpras)

Kepala sekolah pro aktif melakukan pembinaan kepada guru dan tenaga kependidikan baik secara umum dalam setiap pertemuan berkala, maupun secara personal approach kepada masing-masing guru sesuai situasi dan temuan dalam proses belajar mengajar. Kepala sekolah menanggapi secara positif masalah yang dihadapi guru dan bersama-sama berusaha mencari solusi terbaik, bahkan dengan pendekatan agama sehingga guru bisa dengan mudah menerima masukan untuk perbaikan kinerja dan kelancaran proses belajar mengajar." (Informan 4: 2016 )

\section{Kendala yang Dihadapi dalam Menerapkan Strategi}

Dalam menerapkan strategi kendala yang dihadapi kepala madrasah antara lain:

a. Sikap proaktif guru yang berfariasi dalam mencapai implementasi visi dan misi madrasah.

I4 Jurnal al-Fikrah, Vol. V, No. 1 Januari-Juni 2017 b. Sikap profesionalisme guru yang belum terasah dengan baik

c. Masih ada guru yang suka nyaman atau hanya datang kemadrasah disaat jam mengajar .

d. Masih ada guru kurang peduli kepada kegiatan madrasah

e. Sarana prasarana belum lengkap

3. Penerapan Strategi oleh Kepala Madrasah

Cara yang dilakukan kepala madrasah dalam menerapkan strategi diatas:

a. Membuat komitmen dengan tenaga pendidik dan kependidikan dan stakeholder terkait untuk memajukan lembaga.

b. Menyusun EDS (Evaluasi diri sekolah)

c. Menetapkan visi dan misi madrasah

d. Menyusun Rencana Strategik Madrasah

e. Membentuk Tim akreditasi

f. Memberdayakan Komite Madrasah

g. Menjalin kerjasama dengan instansi terkait.

Berdasarkan hasil temuan umum dan temuan khusus penelitian tentang strategi kepala MAN Gunung dalam meningkatkan nilai akreditasi lembaga ditemukan dapat disimpulka ada empat strategi yang dilakukan oleh kepala MAN Gunung Padang Panjang, yaitu:

Hal pertama yang dilakukan oleh kepala madrasah dalam memulai tugasnya adalah menetapkan visi dan misi madrasah. Visi madrasah adalah representasi dari kepala madrasah itu sendiri, apa yang menjadi 
cita-cita yang ingin dicapai dimasa depan pada madrasah yang dipimpinnnya. Sesuai dengan teori yang dikemukakan oleh Mulyasa (2004: 126) menjelaskan bahwa kepala madrasah adalah motor penggerak dan penentu kebijakan madrasah, yang akan menentukan bagaimana tujuan-tujuan dalam pendidikan pada umumnya dapat direalisasikan. Visi adalah cita-cita atau keinginan yang diharapkan dimasa depan, sesuai dengan teori yang dikemukakan Wibisono (2006: 43), "visi merupakan rangkaian kalimat yang menyatakan citacita atau impian sebuah organisasi atau perusahaan yang ingin dicapai di masa depan”. Atau dapat dikatakan bahwa visi merupakan pernyataan want to be dari organisasi atau perusahaan. Visi juga merupakan hal yang sangat krusial bagi perusahaan untuk menjamin kelestarian dan kesuksesan jangka panjang.

Dalam visi suatu organisasi terdapat juga nilai-nilai, aspirasi serta kebutuhan organisasi di masa depan seperti yang diungkapkan oleh Kotler yang dikutip oleh Nawawi (2000: 122), Visi adalah "pernyataan tentang tujuan organisasi yang diekspresikan dalam produk dan pelayanan yang ditawarkan, kebutuhan yang dapat ditanggulangi, kelompok masyarakat yang dilayani, nilai-nilai yang diperoleh serta aspirasi dan cita-cita masa depan”. Untuk merumuskan visi tersebut maka langkah pertama yang dilakukan kepala madrasah adalah menyusun evaluasi diri sekolah (EDS) Sesuai dengan Panduan Evaluasi Diri
Sekolah (2013: 16) Evaluasi secara umum merupakan suatu proses pengumpulan serta pemrosesan data dan informasi yang akan digunakan sebagai dasar pengambilan keputusan, pengelolaan dan pengembangan sekolah. Menurut Sanders dan Sullins (2006: 12) Proses evaluasi melibatkan dua tindakan dasar: (1) pengumpulan informasi sehingga keputusan akan informasi dapat didukung dan (2) menerapkan kriteria informasi yang tersedia untuk mencapai suatu keputusan yang benar. Evaluasi diri yangdimaksudkan adalah proses pengumpulan data dan pemrosesan data dan informasi yang digunakan untuk pengambilan keputusan pada MAN Gunung Padang Panjang.

Hasil evaluasi diri sekolah diolah menggunakan analisa swot. Analisis SWOT adalah suatu analisa penyusunan strategi perusahaan atau organisasi yang bersifat tunggal. Ruang lingkup bisnis tunggal yang bersifat domestik atau internasional. Menurud Fredi Rangkuti (1995: 15) pakar analisis SWOT Indonesia analisis swot adalah:

"Identifikasi berbagai faktor secara sistimatis untuk merumuskan strategi perusahaan. Analisa ini didasarkan atas pola hubungan atau interaksi antara unsur -unsur internal, kekuatan dan kelemahan terhadap unsur-unsur eksternal yaitu peluang dan ancaman (Rahman: 2011)

Hasil identifikasi yang dihasilkan dengan analisa swot adalah: 


\section{a. Strength (Kekuatan)}

Kepala madrasah bersama civitas akademika MAN Gunang berusaha menginventarisir semua kekuatan:

1). Guru berpendidikan $S 1$ dan $S 2$

2). Motivasi belajar siswa cukup tinggi

3). Komitmen guru melaksanakan tugas tinggi

4). Sarana Prasarana cukup memadai

5). Rangking dan reputasi baru mulai bergerak kearah yang lebih baik

6). Lingkungan belajar sangat kondusif

7). Bakat dan potensi siswa cukup memadai

8). Dukungan masyarakat sedang

9). Guru mampu mengembangkan kreatifitas pembelajaran.

\section{b. Weakness (Kelemahan)}

Dari evaluasi madrasah yang dilakukan ditemukan beberapa kelemahan:

1). Penyebaran guru bidang studi belum merata

2). Belum semua guru memperoleh pelatihan

3). Buku pegangan siswa belum memadai

4). Latar belakang orang tua siswa masih rendah

5). Rata-rata nem input siswa rendah

6). Minat masyarakat untuk memasukkan anaknya ke madrasah rendah.

\section{c. Opportunities (Keberuntungan)}

1). Kualitas pembelajaran dapat ditingkatkan

2). Banyaknya sekolah tingkat SLTP disekitar

3). Banyaknya kesempatan siswa untuk masuk Perguruan Tinggi melalui jalur PMDK

I6 Jurnal al-Fikrah, Vol. V, №. 1 Januari-Juni 2017
4). Kesempatan bagi siswa masuk PTAIN cukup besar

5). Kesempatan untuk memperoleh beasiswa dari Kemenag, Pemda, Kota Padang Panjang dan Pemda Propinsi Sumatera Barat.

\section{d. Threat (Ancaman)}

1). Lokasi madrasah jauh dari pusat kota

2). Persaingan SLTA di Padang Panjang cukup tinggi

3). Masih terjadi perkelahian pelajar disekolah sekitar

4). Risiko bahaya narkoba cukup tinggi

5). Masih banyak siswa yang tinggal jauh dari lokasi sekolah.

Berdasarkan teori di atas maka visi MAN Gunung Padang Panjang dengan mempertimbangkan efektifitas sebuah visi seperti: (1). Imagible (dapat di bayangkan), (2). Desirable (menarik), (3). Feasible (realities dan dapat dicapai), (4). Focused (jelas), (5). Flexible (aspiratif dan responsif terhadap perubahan lingkungan), (6). Communicable (mudah dipahami). Maka disusunlah visi MAN Gunung Padang Panjang "Unggul dalam Imtaq Cerdas Dalam Berilmu Mulia dalam Berakhlak"

\section{KAJIAN PENELITIAN YANG RELEVAN}

Untuk mendukung kepentingan penelitian akan dikemukakan beberapa penelitian yang berkaitan dengangan penelitian ini: 
Penelitian Hadi (2014) Strategi Kepala Madrasah dalam Meningkatkan Mutu Pendidikan Pada Min Buengcala Kecamatan Kuta Baro Kab Ace Besar. Kesimpulan dalam penelitian ini Meningkatkan efektifitas guru dan pembelajaran dengan cara pengembangan guru dan staf merupakan pekerjaan yang harus dilakukan kepala madrasah dalam manajemen personalia pendidikan, yang bertujuan untuk mendayagunakan guru dan staf secara efektif dan efisien untuk mencapai hasil yang optimal, namun tetap dalam kondisi yang menyenangkan. Meningkatkan kompetensi guru melalui seminar dan pelatihan. Kepala madrasah selalu memberi motivasi bagi guru yang malas dan kurang berprestasi,dengan pelatihan serta reward dan punishman.

Penelitian memiliki hubungan dengan penelitian penulis sama sama menggunakan strategi untuk mencapai tujuan perbedaannya penelitian ini fokus pada peningkatan mutu pendidikan, sedang yang penulis teliti berkaitan dengan peningkatan nilai akreditasi.

Penelitian Aliyansyah (2012) Strategi Kepala Madrasah Sebagai Pemimpi dilakukan, maka hasil yang diperoleh adalah sebagai berikut: Meningkatkan Mutu Input Pendidikan, Meningkatkan Mutu Proses Pendidikan, Meningkatkan Mutu Output Pendidikan. Hasil penelitian diatas ada hubungannya dengan penelitian penulis dalam hal strategi kepala madrasah dalam meningkatkan mutu pendidikan.

\section{PENUTUP}

\section{Kesimpulan}

Berdasarkan pembahasan pada bab sebelumnya, maka dapat penulis simpulkan:

1. Strategi kepala MAN Gunung Padang Panjang dalam meningkatkan nilai akreditasi lembaga adalah sebagai berikut:

a. Membentuk tim akreditas madrasah

b. Menyatukan persepsi seluruh stakeholder madrasah untuk meningkatkan nilai akreditasi lembaga

c. Menyusun renstra visi dan misi madrasah dengan menyusun evaluasi diri dan merumuskannya dengan analisis swot.

d. Mengajak tokoh masyarakat berperan aktif memajukan madrasah

e. Mengupayakan peningktan de;apan standar pendidikan.

2. Kendala yang dihadapi dalam menerapkan strategikendala yang dihadapi kepala madrasah antara lain:

a. Sikap proaktif guru yang berfariasi dalam mencapai implementasi visi dan misi madrasah.

b. Sikap profesionalisme guru yang belum terasah dengan baik

c. Masih ada guru yang suka nyaman atau hanya datang kemadrasah disaat jam mengajar.

d. Masih ada guru kurang peduli kepada kegiatan madrasah

e. Sarana prasarana belum lengkap. 
3. Penerapan Strategi oleh Kepala Madrasah Cara yang dilakukan kepala madrasah dalam menerapkan strategi di atas:

a. Membuat komitmen dengan tenaga pendidik dan kependidikan dan stakeholder terkait untuk memajukan lembaga.

b. Menyusun EDS (Evaluasi diri sekolah)

c. Menetapkan visi dan misi madrasah

d. Menyusun Rencana Strategik Madrasah

e. Membentuk Tim akreditasi

f. Memberdayakan Komite Madrasah

g. Menjalin kerjasama dengan instansi terkait.

\section{Saran}

1. Untuk MAN Gunung Padang Panjang agar dapat mempertahankan prestasi yang telah diperoleh saat ini dengan akreditasi "A".

2. Untuk tenaga pendidik dan kependidikan untuk dapat meningkatkan kompetensi profesional dengan melanjutkan pendidikan kejenjang S2 dan S3.

3. Untuk pemerintah kota Padang Panjang diharapkan memberi perhatian lebih kepada MAN Gunung Padang Panjang

4. Untuk Kementerian Agama RI diharapkan membantu menambah tenaga pendidik dan kependidikan, serta melengkapi sarana dan prasarana.

5. Untuk para alumni pro aktif membantu memajukan madrasah dalam ide dan bantuan lain yang tidak mengikat.
6. Bagi madrasah lebih pro aktif membuat jaringan dengan instansi terkait dan lembaga yang dapat membantu kemajuan madrasah.

\section{KEPUSTAKAAN ACUAN}

Abdul Halim Hanafi, (2010). Metodologi Penelitian Kependidikan, Untukpenulisan Skripsi, Tesis dan Disertasi, Batusangkar: STAIN Batusangkar Press.

Anas Sudjono, Pengantar Statistik Pendidikan, Jakarta: Rajawali Press, Cet-ke 2.

Agus Irianto, (2011). Pendidikan Sebagai Investasi dalam Pembangunan suatu Bangsa, Jakarta: Kencana, cet ke I.

Abdoel kadir, Abdul Wahab. Organisasi Konsep dan Aplikasi. (Tangerang: Pramita Press, cet. pertama, 2006).

Buseri, Kamrani, Peran Spiritualitas (Agama) dalam Penyelenggaraan Kepemimpinan, makalah disampaikan pada Seminar dan Orasi Ilmiah dalam rangka Dies Natalis ke $24 \&$ Wisuda Sarjana ke $19 \&$ Pascasarjana ke 2 STIA Bina Banua Banjarmasin, tanggal 15 dan 16 September 2006.

Bedjo Siswanto, (1990). Manajemen Moderen Konsep dan Aplikasi, Bandung Sinar Baru: Cet I.

Bedjo. (1996). Prhatian Orang Tua dari Keluarga dalam Pendidikan anakanaknya. Majalah Ilmiah Universitas Udayana. Bali: Universitas Udayana. 
Bass dan Avolio, B.J, (2009). Multifactor Leadership Questionnaire Report, California: Mind Gardens, 1996, Departemen agama RI, Al-qur'an dan terjemahannya, Jakarta PT. Sygma Examedia Arkalema.

Departemen Pendidikan Nasional, Panduan KTSP, (Jakarta: Depdiknas 2006).

Edward F.L.Brecht, (1959). The Principle and Practice of Management, Green and company, New York.

George R.Terry, (1960). Principle of Management, Richard D Irwin Inc, Homewood Illinois.

Hj.Siti Rodiyah, (2012). Partisipasi Masyarakat dalam Pengambilan Keputusan, Keputusan dan Perencanaan di Sekolah. STAIN JEMBER Press, Cet Ke 1.

Husaini Usman. (2002). Manajemen Teori Praktik \& Riset Pendidikan. (Jakarta: Bumi Aksara.

James L Gibson, et. all, (1988). Organisasi Perilaku, Struktur, Proses, Alih bahasa: Djarkasih, Jakarta: Erlangga.

Ibnu Syamsi, (1995). Pengambilan Keputusan dan Sistem Informasi, Jakarta,Sinar Grafika, cet ke 2.

Keith Davis, Human Relations at Work, (New York, San Francisco, Toronto, London: 1962). Hlm.15-19 dalam wikipedia download tanggal 28-04-2013 jam 23.15.

Keith Davis, and John W. Newstrom. (1985). Human Behaviour at Work:
Organizational Behaviour. (New York Mc. Graw-Hill Inc.

Lipoto, (1998). Kepemimpinan Kepala Madrasah, Bandung: Tarsito.

Lipham, James, et.al: The Principles, Consept. Competencies, Cases, By Longman Inc, 1560 Brodway,New york, N,Y,10036.

Mulyasa. E, (2004). Menjadi Kepala Sekolah Profesional, dalam Rangka Mensukseskan MBSdan KB K. Bandung: PT. Rosdakarya.

M.Quraish Shihab, Tafsir Al-Misbah (Pesan, Kesan dan Keserasian Al-Qur'an), Jakarta, Lentera Hati, Volume 6, Cet I, 2002 Publish By Dokter Kota on Kategory: Community Development download tanggal 28-03-2013.

Pahlawan Kayo, Khatib RB, (2005). Kepemimpinan Islam \& Dakwah, Jakarta: Amzah, cet. I.

Ralph C.Davis, (1951). The Fundamental of Top Manajement, Harper dan Bross, New York.

Robbins, S.P. (1984). Management, Consepts and Practices, New Jersey: (Prentice Hall, Inc Englewood Cliffs,

Ramayulis, (2011). Ilmu Pendidikan Islam, Jakarta: Kalam Mulia.

Raihani, (2010). Kepemimpinan sekolah Transformatif, Yogyakarta, PT, Lkis Printing Cemerlang, Cet Ke -2 . 
Robbins, S.P. (1984). Management, Consepts and Practices, New Jersey: (Prentice Hall, Inc Englewood Cliffs.

Ralph C. Davis, (1951). The Fundamental of Top Manajement, Harper dan Bross, New York.

Sondang, P, Siagian, Ph.D, (1974). Sistem informasi untuk Pengambilan Keputusan, PT Gunung Agung Jakarta.

Slameto, (1995). Belajar dan faktor-faktor yang mempengaruhi, Jakarta: Rineka Cipta.
Suharsimi Arikunto, (2003). Manajemen Penelitian, Jakarta, Rineke Cipta.

Sutisna Oteng, (1989). Administrasi pendidikan, Bandung: Angkasa.

Victor H. Vroom dan Jago, Arthur G. (1988). The New Leadership: Managing Participation in Organizations. Englewood Cliffs, New Jersey: Prentice Halls.

Winardi, (1990). Asas-asas Manajemen, Bandung, Mandar Madju. 